Revue Française de Civilisation Britannique

\title{
Rhoda Power, BBC Radio, and Mass Education,
}

\section{2-1957}

Rhoda Power, la radio de BBC, et l'education universelle, 1922-1957

\section{Laura Carter}

\section{(2) OpenEdition}

\section{Journals}

Electronic version

URL: https://journals.openedition.org/rfcb/7316

DOI: $10.4000 /$ rfcb.7316

ISSN: $2429-4373$

\section{Publisher}

CRECIB - Centre de recherche et d'études en civilisation britannique

\section{Electronic reference}

Laura Carter, "Rhoda Power, BBC Radio, and Mass Education, 1922-1957", Revue Française de Civilisation Britannique [Online], XXVI-1 | 2021, Online since 05 December 2020, connection on 05 January 2022. URL: http://journals.openedition.org/rfcb/7316 ; DOI: https://doi.org/10.4000/rfcb.7316

This text was automatically generated on 5 January 2022.

\section{(9) $\odot \Theta \Theta$}

Revue française de civilisation britannique est mis à disposition selon les termes de la licence Creative Commons Attribution - Pas d'Utilisation Commerciale - Pas de Modification 4.0 International. 


\title{
Rhoda Power, BBC Radio, and Mass Education, 1922-1957
}

Rhoda Power, la radio de BBC, et l'education universelle, 1922-1957

\author{
Laura Carter
}

\section{AUTHOR'S NOTE}

I would like to thank Peter Mandler and Rozemarijn van de Wal for supporting and advising me on the research behind this article, and Louise North of the BBC Written Archives Centre and the anonymous reviewer for this journal for their help in the preparation of this article. The $\mathrm{BBC}$ copyright content reproduced in this article is courtesy of the British Broadcasting Corporation. All rights reserved.

\section{Introduction}

1 In an October 1934 article in the BBC's educational journal The Listener, Scottish writer and activist Naomi Mitchison reviewed the latest set of pamphlets for the BBC's 'Broadcasts to Schools'. The review positioned the BBC's radio lessons for schools as a technological milestone in teaching, introducing a third element into the classroom space that had previously been limited to the linear, teacher-pupil relationship. Mitchison described how the broadcaster must connect as much with the 'ordinary, flesh-and-blood teacher, who is standing by', as with the room full of pupils listening to the lesson on the radio. Herself an historical novelist, Mitchison awarded special praise to the BBC's series of History broadcasts by Rhoda and Eileen Power. They were regarded as being particularly successful in cultivating this new, triangular pedagogical relationship:

And then World History with Eileen Power, and British History with Rhoda Power and any parent or teacher knows that the two Powers have a way with history: it 
just comes alive in their hands. One looks forward particularly to the dramatic interludes.

2 In 1934 BBC broadcasting for schools was thriving, having begun only a decade earlier when the British state education system was itself undergoing considerable reform and expansion. This article considers the relationship between $\mathrm{BBC}$ radio and mass secondary education in Britain through the life of the innovative schools History broadcaster Rhoda Dolores Le Poer Power (1890-1957). I argue that during the midtwentieth century the $\mathrm{BBC}$ was closely aligned with mainstream educational thinking, and that its broadcasting structures and practices largely reproduced the stratification of social knowledge seen in Britain's evolving secondary school system between the 1920s and the 1950s. Through the work of Rhoda Power, the article also shows how the $\mathrm{BBC}$ created unique spaces for women to participate in and lead educational thinking, at a time when their influence within elite education in universities was diminishing.

3 From the formation of the BBC as a consortium in 1924, education was at the heart of the institution. John Reith, the first BBC Director-General (1922-38), famously professed the idea that the BBC's purpose was to 'inform, educate, and entertain'. Historians have carefully assessed the achievements of Reith's mission. The historiographical consensus is that the $\mathrm{BBC}$ was ultimately a paternalistic project; a technological intervention in British mass culture that aimed to guide, edify, and uplift working-class tastes and align them with middle-class expectations in a liberal democracy. ${ }^{2}$ Moreover, as David Hendy has argued, the BBC in the 1920s was also an emotional playground for a generation of psychologically disconnected individuals in the wake of the First World War. ${ }^{3}$ The midcentury BBC has therefore been well defined as a cultural and intellectual project. Yet these elite discourses were also deeply entwined with urgent, practical concerns about the shape and purposes of mass education in Britain between the wars. Through a consideration of $\mathrm{BBC}$ broadcasting for schools, this article suggests that the BBC's liberal paternalism must be understood as both a Victorian legacy and a product of contemporary interwar educational discourses.

4 This article now proceeds in three parts. It first outlines how the BBC initially developed its offering for school audiences in the 1920s and 1930s, and how this related to broader educational structures and agendas in Britain during this period. The second section of the article introduces the History broadcaster Rhoda Power, doyenne of BBC schools broadcasting between the 1920s and 1950s. Her experiences in travel and ethnographic observation are used to explain the development of her quasianthropological pedagogical philosophy, which was hugely influential on BBC broadcasting for schools in the period up to the 1960s. The final, third section explores how this philosophy was put into practice in History lessons for schools on the radio. It also examines the evolution of the BBC's mid-century educational project during and after the Second World War, as Britain's mass education system expanded as part of the post-1945 welfare state.

\section{BBC education and the development of broadcasting for schools, 1924-39}

BBC broadcast lessons produced specifically for schools, which are the focus of this article, have not received much scholarly attention outside of specialist history of education literature. ${ }^{4}$ One simple explanation for this is perhaps that at the $\mathrm{BBC}$ 
Written Archives Centre (located in Caversham, near Reading) the files and scripts for schools broadcasting are organised and housed separately, making it difficult to produce integrated histories of general and schools broadcasting for subjects such as History, Music, or Science featured on the BBC. ${ }^{5}$

6 A second, more salient reason, is the BBC's longstanding but complex relationship with the formal adult education movement in Britain. Upon the BBC's foundation in 1922, it was imagined as an institution that would bolster and augment adult education. The BBC launched a joint inquiry with the British Institute of Adult Education which published its findings in March $1928 .{ }^{6}$ The report, New Ventures in Broadcasting, was an ambitious statement of broadcasting's reach. It recommended an educational publication (realized as The Listener from 1929), the creation of an advisory council, and the setting up of listening groups. ${ }^{7}$ The report ultimately stressed that the BBC had a more universalist remit than existing bodies, and that it was not intending to supplant the Workers' Educational Association (WEA). The WEA was formed in 1903 and grew rapidly over the course of the 1920s and 1930s, delivering classes to workers in communities all over Britain. It had close links with the labour movement but was committed to a liberal, literary, and non-partisan educational programme, much like the BBC's. ${ }^{8}$

7 The BBC had exploited these synergies in early experiments, but liaising with adult education classes on the listening end proved complicated due to administrative decentralization, and ultimately not a financial priority when the corporation faced cuts. ${ }^{9}$ The report instead argued that BBC educational talks on the radio for adults were to be far more general than what the WEA offered. The BBC positioned itself as reaching out to new constituents whose appetites for education had been stimulated by the First World War and enfranchisement, especially women and school leavers. ${ }^{10}$ Promoting 'active' rather than 'passive' listening was a chief concern here. ${ }^{11}$ These differences in conception meant that by the mid-1930s adult education was all but absorbed into the Talks branch of the BBC. During that decade, the BBC transmitted a vast array of general educational talks, lectures, and debates, given by figures including Vita Sackville-West, H. G. Wells, and E. M. Forster. Much of this activity was the result of the appointment of Hilda Matheson as Director of Talks in 1927, whose social connections facilitated the introduction of the interwar intelligentsia to mass radio communication. ${ }^{12}$

8 Meanwhile, radio broadcast lessons for schools developed along a different track from the mid-1920s. Although the Schools Broadcasting Department was technically a subdivision of the Talks branch before 1939, making broadcasts designed to be played directly into the classroom required the $\mathrm{BBC}$ to engage with the complex and highly decentralised British education system. Since the late-nineteenth century, the British state had been expanding education, gradually requiring children to stay in compulsory schooling for longer and to acquire knowledge beyond the traditional elementary subjects of reading, arithmetic, and scripture. Education was delivered by local governmental bodies called local education authorities (LEAs), established by the 1902 Education Act for England and Wales. ${ }^{13}$

9 After the First World War ambitious legislative reforms were passed: the 1918 Education Act (known as the Fisher Act) for England and Wales, and the Education (Scotland) Act of 1918. Both Acts were primarily intended to expand secondary education (schooling beyond the age of eleven), although the Scottish Act was far more 
robust and successful in achieving this in the long term. ${ }^{14}$ In the interwar period in England, most working-class children attended an elementary school up to the age of twelve, perhaps fourteen. The provision of secondary education during those final years varied drastically depending on the region and gender. Middle-class children either went to independent (private) schools or selective grammar schools (for which fees were paid by most attendees before the Second World War), giving them access to school-leaving qualifications and further education. ${ }^{15}$

This was the fragmented and stratified education system into which the BBC entered when it began experimental transmissions for schools in the early 1920s. Broadcasts for schools needed to reach out to this diverse set of educational contexts, shaped by class, gender, region, age. In line with the corporation's ethos, the BBC was particularly concerned to produce content for the slowly expanding secondary-school audiences, which would transmit its liberal, civilising message to soon-to-be citizens. The early phase of schools work was patchy since the BBC was insufficiently connected to the LEAs. Moreover, the impoverished elementary schools rarely had the adequate equipment, such as wireless sets, to receive schools broadcasts, and teachers were highly sceptical of the efficacy of classroom broadcasting. ${ }^{16}$

11 The BBC's National Advisory Committee on Education met in May 1924 and heard a report on the first experimental schools transmissions, which identified the "lack of physical presence of the lecturer' as the biggest problem. ${ }^{17}$ By June 1926 it was estimated that between 1,500 and 2,000 London schools were listening in. Of these, 70 per cent were elementary schools, 16 per cent private, 10 per cent high schools and secondary schools, and 4 per cent Central Schools (a new form of technical and vocational secondary education). ${ }^{18}$

12 In 1927 the Carnegie Trust funded a special investigation into the value of schools broadcasting and a pilot study was conducted in Kent. The Kent inquiry enabled the $\mathrm{BBC}$ to directly observe listening conditions in schools. ${ }^{19}$ It was the first step in a sustained partnership that would eventually see BBC Education Officers deployed on the ground in schools, reporting back to the BBC. Since the BBC's actual Listener Research Department was not established until 1936, this schools work was probably the BBC's longest-running and most successful listener liaison project. ${ }^{20}$ At the centre of the investigation into schools was Mary Somerville, the BBC's first female producer recruited by Reith in 1925, who became Director of Schools Broadcasting in 1929. ${ }^{21}$

13 Following the Kent inquiry, the Central Council for Schools Broadcasting (CCSB) was formed in 1929. The CCSB was charged with both the educational responsibility for programme proposals at the transmitting end, and with helping schools at the listening end. The CCSB was made up of a combination of representative and nominated members from government departments, unions, voluntary, and educational organisations. There was a Sub-Committee (and eventually a Sub-Council) for Scotland, and subject Sub-Committees for Geography, History, Modern Languages, English Literature, and Music. ${ }^{22}$ By 1932 the Schools Department had five full-time members of staff in London and two in Scotland, all reporting to Somerville as Director. ${ }^{23}$ Although a separate menu of schools programmes were produced for both Welsh and Scottish schools, Scotland enjoyed a lot more autonomy. Wales was not even recognised as a separate entity by the BBC until 1937, and Welsh listeners received their radio programmes as part of the 'Western' region of England. ${ }^{24}$ 

rose consistently over the 1930s. The last few years of the 1930s were a period of considerable momentum, with more schools programmes being broadcast than ever before. ${ }^{25}$ Meanwhile, the CCSB had worked to scrutinise how schools actually used the broadcasts. ${ }^{26}$ Although practices varied widely, there was widespread demand for material to help teachers integrate and mediate the radio broadcasts. The first accompanying 'Broadcasts to Schools' pamphlets, like those reviewed in our introduction, were produced for the autumn term of $1927 .{ }^{27}$ They became an essential tool in the mission to promote 'active' listening, even more important when the BBC assumed state propogandist functions during the Second World War. The architects of the BBC's educational mission ultimately hoped that the schools broadcasts would ingrain the habit of active, intelligent listening in adolescents and future citizens. ${ }^{28}$

\section{Rhoda Power, time travel, and 'oral vision'}

In 1928-9 an inquiry was carried out specifically with History teachers to find out how they were using the BBC's History broadcast lessons. It found that elementary schools tended to regard the broadcasts as a 'weekly visit from an expert', given that teachers were highly unlikely to be subject specialists. ${ }^{29}$ From the late 1920 s, the History 'expert' speaking to schoolchildren over the airwaves was very often Rhoda Power. She was a key figure in BBC schools broadcasting in the mid-twentieth century and was also a prolific author of children's History books. ${ }^{30}$ Her career at the BBC spanned from her first afternoon talks on 'Village Life 700 years ago' for Women's Institute listeners in 1927 until her death in 1957. She was awarded an MBE in 1950 for her contribution to History education. Indeed, Mary Somerville recorded her amazement after Rhoda's passing that she had never pursued a broadcasting career outside of the Schools Department. $^{31}$

Rhoda Power's BBC work has often been appended to the career of her sister, the economic historian Eileen Power (1889-1940). Eileen was an essential source of historical expertise and guidance to Rhoda when writing scripts (up to her premature death in 1940), but Rhoda and Eileen's joint endeavours represented only a small segment of Rhoda's overall broadcasting career. ${ }^{32}$ This article therefore explores Rhoda's distinctive contribution, arguing that her innovations in History broadcasting came to define the BBC's mid-century, educational project.

Rhoda's personal experiences shaped her ideas about how to communicate History to a mass audience. Rhoda Power was the middle sister, one year younger than Eileen and one year older than Beryl Power, a prominent civil servant who devoted much of her career to studying international labour conditions. ${ }^{33}$ The Power girls were born into a middle-class family in Cheshire and attended secondary school in Oxford. Whilst both her sisters studied History at Girton College, Cambridge, Rhoda attended the University of St Andrews between 1911 and 1914, taking courses in Greek, German, French, Political Economy, and Economic History. ${ }^{34}$

Rhoda's professional life was defined by travel and education. After a year teaching in North America after university, she spent eighteen months in Rostov-on-Don in Russia teaching the daughter of a bourgeoisie trader. This post was interrupted by the outbreak of the Russian revolution in March 1917. Rhoda lived for a while in a British Consul House until anarchy engulfed the region. She was forced to travel covertly

Revue Française de Civilisation Britannique, XXVI-1 | 2021 
across Russia in the middle of 1918, picking up a troop train in Moscow up to the Murman coast and living for seven weeks in a cattle shed. ${ }^{35}$ Rhoda's Russian diaries began as light-hearted and comedic, but progressed into a combination of news bulletins and longer, descriptive entries. They reveal her conflicted and evolving political subjectivities: an aversion to the excesses of the Russian bourgeoise ('pearls the size of cherries in their ears - it is not only vulgar but unsafe'), sympathy for the plight of the peasants, and strands of a characteristically British, middle-class antisocialism. ${ }^{36}$ Rhoda's first-hand experience of the chaos and violence of Bolshevism in Russia dampened her Leftist instincts, leading her towards a moderate, progressive politics that would ultimately align with the democratic ethos of the BBC.

Rhoda pursued writing and journalism full time in London during the 1920s, eventually leading to regular work at the BBC from 1927 as an ad-hoc scriptwriter and broadcaster. She was contracted part-time from July 1937 and then full-time from the outbreak of the Second World War in September 1939. ${ }^{37}$ By 1945 she was labelled as 'worth her weight in gold', and was amongst the BBC's highest-earning women professionals. ${ }^{38}$ After the Second World War she arranged to take an annual thirteenweek sabbatical from to travel..$^{39}$ These trips sharpened Rhoda's anthropological eye, as she observed the habits, customs, and practices of non-Western societies. For example, she spent the summer of 1936 in New Mexico. She wrote to a BBC colleague, 'I am living in a mud house in an Indian pueblo where one of the squaws is teaching me how to make pottery', going on to describe her hopes of living in close contact with the 'shy' women of wandering Navajo tribes. ${ }^{40}$ Rhoda also travelled extensively across the Americas over 1946-7, partly to collect 'exhibits' of everyday life for educational use in Britain. In Ecuador, Bolivia, and Brazil, Rhoda visited markets and immersed herself in local culture. ${ }^{41}$ She spent Easter of 1947 in Guatemala with the people of Chichicastenango, and described the following episode on Good Friday:

...we began to witness a scene so reminiscent of the middle ages, that I could almost have believed myself back in medieval Europe watching the craft gilds celebrating Corpus Christi Day. Every detail of the scene was reenacted by these Indians. ${ }^{42}$

Foreign travel was an exercise in historical time travel for Rhoda. Her sister Eileen made strikingly similar comments about her visit to India in 1921, comparing the shops and artisans in the bazaars to medieval Europe: 'What takes me all the time is not much a difference between West and East as a difference between modern and medieval'. ${ }^{43}$ Both women saw non-Western societies as providing experiential access to the premodern past through an emphatically white, imperial gaze. As Billie Melman explains of their generation, '...the construction of a collective historical identity for western women coincided with the formation of colonial identity'. ${ }^{44}$ Both Rhoda and Eileen's time-travel narratives echoed contemporary discourses of British social anthropology, which advocated a universalist idea of human culture. Eileen was enthusiastic about this as an academic, historical methodology via her networks at the London School of Economics. ${ }^{45}$

21 Rhoda used the anthropological frame to develop modern, educational ideas for the metropole. She argued that History was simply part of a greater and unfolding, story of human culture. She theorized that ordinary children listening to the radio might come to understand past societies and cultures by approaching historical scenes as ethnographic observers. In a 1932 lecture she pleaded for the 'humanizing of the history lesson', arguing that 'If [history] is to be pleasurable and valuable, it must give one an intimate knowledge of human beings, not an outline of facts, nor a mere 
grouping of certain aspects under headings. ${ }^{46}$ Humanizing History on the radio meant making people 'see through their ears', tapping into the listener's 'oral vision' ${ }^{47}$

The BBC valued Rhoda Power as an educational expert, but not as an intellectual. After receiving a series of criticisms of her talks in 1930, the CCSB History Sub-Committee felt that she 'should refrain from dealing with the future' ${ }^{48}$ They were sanctioning her to have authority in pedagogy, but not in politics. As Kate Murphy's research has shown, the $\mathrm{BBC}$ was a progressive place for women to work between the wars, but gendered codes still applied. ${ }^{49}$ This delicate paradox was captured in the foreword to the 1934 'Woman's Broadcasting Number' of the Radio Times by Mary Agnes Hamilton, which announced: 'In broadcasting, as in politics, men and women work on a genuine basis of equal and common concern-and, moreover, of equal pay!', before going on to describe the aural benefits of hearing a feminine voices on the airwaves..$^{50}$ As an unmarried, educated middle-class woman with no children, Rhoda fit the BBC's ideal type of professional woman. By remaining in the sphere of education she played by the rules of the institution's gendered culture of expertise, whilst still satisfying her own personal desires for self-expression and public service. ${ }^{51}$

\section{History broadcasting and the BBC's mid-century educational project}

Rhoda Power's broadcasting career, 1927-57, represents a distinctive, mid-century era of $B B C$ education, extending from the interwar period to the climax of post-1945 social democracy. As we have already seen, the BBC's work with schools emerged in tandem with state educational reform after 1918. Although budget cuts and teachers' pay disputes slowed the pace of reform during the 1930s, there was a rising consensus that the expansion of secondary education was necessary to meet the needs of a democratic state and modern economy. The BBC noted optimistically in its Yearbook for 1931 that 'The reorganisation of elementary education at present taking place in England is opening the door, as never previously, to experiment with new methods.' ${ }^{52} \mathrm{Rhoda}$ Power's 'oral vision' methodology permeated pedagogical practice within BBC schools broadcasting throughout this period, helping the $\mathrm{BBC}$ to respond to and reflect this newly emerging mass education system.

Rhoda translated the 'oral vision' theory into practice on the radio with the 'illustrated talk', which included dramatic interludes with sound effects, dialogue, and music. In her obituary for Rhoda, Mary Somerville indicated that dramatic interludes in radio talks were originally suggested by Eileen. ${ }^{53}$ The idea was developed, finessed, and practiced by Rhoda. In her 1928 series 'Boys and Girls of Other Days', Rhoda first experimented with sound effects such as cheering crowds, a marching regiment, spinning wheels, and the use of extant songs. ${ }^{54}$ The noises were initially improvised live in the studio, but as the technology improved, pre-existing recordings could be cut in. The $\mathrm{BBC}$ gradually amassed a library of sound effects, including the crowing of 'some very ancient birds' recorded outside the Tower of London..$^{55}$ Rhoda researched old music and lyrics in the library, and the BBC often arranged live singers to accompany her. As the technique developed, she made consistent efforts to ensure each interlude was technically adapted to the suit the age range targeted by the series. ${ }^{56}$ 

'illustrated talk' concept: a typical programme lasted twenty minutes, fifteen of which were taken up by three dramatic interludes, plus one and a half minutes of sound effects. ${ }^{57}$ By the mid-1930s full historical dramas were being produced. For example, in June 1933 a schools History broadcast entitled 'Caxton's Printing Press' was aired, which took the form of a dialogue between an ordinary woman and a scribe. The woman explains to the scribe why the coming of printing is of benefit to 'the people'. The conversation is set amidst crowds outside Caxton's workshop in 1477, whilst Edward IV is inside inspecting the new press. ${ }^{58}$ Often in Rhoda's broadcasts the 'great men' formed the background in this way, whilst an 'ordinary' voice was foregrounded to describe the effect of social change on the masses.

Power's technique was readily used by other broadcasters, as it became an entrenched device in broadcasts for schools and school leavers. ${ }^{59}$ For example, in the British History series for 1937, the children's author Hugh Chesterman wrote a series of dramatic interludes to illustrate how education and food had changed between the sixteenth century and the present day. ${ }^{60}$ The 'illustrated talk' was equally as popular in Scotland; R. L. Mackie's 'Round the Clock in a Thirteenth Century Burgh' episode, part of the 1935 regional 'Scottish Social History' series, featured a merchant and his family waking up to the sights and sounds of Dundee High Street..$^{61}$ The dramatic form added emotion and everydayness to the historical setting. By the end of the 1930s the aim within the Schools Broadcasting Department was consistent: 'to make the child the explorer of his own reality', and this had to involve 'children's feelings as well as their minds' ${ }^{62}$ The technique was considered a genuine educational novelty, even attracting praise from NBC in the USA for its originality. ${ }^{63}$

The illustrated talk technique undoubtedly contributed to the growing success of $\mathrm{BBC}$ History broadcasts for schools during the 1930s. In 1938 it was reported that 10,000 classes of children were listening to weekly History broadcasts, divided between three courses for different age ranges. ${ }^{64}$ Syllabuses from 1929-35 had varied year on year, but by the mid-1930s the Department had hit upon a winning formula: 'World History' for 9-11 year olds (juniors), 'British History' for 11-14 year olds (post-primary/secondary), and 'History in the Making' for the 13-plus group (leavers). For each series there were typically twelve talks in the autumn term, ten in the spring term, and eight in the summer term. ${ }^{65}$ The CCSB continued to consult and inquire over how schools were listening, debating the merits of teaching via topics over straight chronology. But it remained impossible to discern how many schools listened regularly and fully integrated the broadcasts into their teaching. ${ }^{66}$

Although the war forced the $\mathrm{BBC}$ to significantly pare back services, Schools Broadcasting was ringfenced and continued in a reduced capacity. The techniques and ethos that had been established in the 1930s were maintained and carried over into the postwar period. Mary Somerville's wartime team in its new countryside location was comprised of twenty-two people and six typewriters in 'two small rooms', and it was no longer possible to invite myriad live broadcasters to contribute to programmes. ${ }^{67} \mathrm{In}$ spite of this, Schools Broadcasting ended the Second World War in a stronger position than when it started, with more staff, more programmes, and more listeners. It was estimated after 1944 that between one half and one third of all schools were making use of the broadcasts in some way. ${ }^{68}$ 

BBC's conception of its audience. Rather than remaining an agent of top-down cultural change on the Reithian model, the experience of wartime broadcasting made the BBC more flexible. Although the civilising mission remained, after 1945 the BBC was more stratified. In 1945 the National Service was split into the Light Programme (popular culture, based on the hugely popular wartime Forces Programme), the Home Service ('middlebrow' culture), and the Third Programme (high culture), reflecting different tastes and varied listening habits. ${ }^{69} \mathrm{At}$ the same time, the Welsh and Scottish Regional Programmes ceased and were replaced with their own Scottish and Welsh Home Service options. ${ }^{70}$

The war ultimately strengthened the BBC's notion of its role in promoting democratic citizenship, part of a wider, wartime self-narrative that contrasted European totalitarianism with Britain's moderate, democratic self-image. The Schools Broadcasting Department followed this trend, in History broadcasting especially. Programmes were produced to establish firmer links between historical events and the responsibilities of democratic citizenship, especially for senior pupils. ${ }^{71}$ Helen Duncan, a programme assistant from 1942, explained: '...in a democratic state every child remotely capable of it should be given the kind of history that makes a background for intelligent thinking about current affairs' ${ }^{72}$ This impulse only heightened during postwar reconstruction and did not diminish until the 1960s. ${ }^{73}$

British secondary education was fully reorganised after the Second World War. Through the engine of the post-1945 welfare state, many of the stratifying trends that the BBC had been tracking in its programme offerings during the 1930s were fully realised. The 1944 Education Act (the Butler Act) mandated that all English and Welsh LEAs had to provide a variety of secondary educational provision and abolished fees in the grammar schools. Most (although not all) LEAs responded by implementing a tripartite or bipartite system and used the 'eleven-plus' examination to allocate pupils aged 11-15 into either academic grammar schools, non-academic secondary modern schools, or vocational technical schools. Schools broadcasting subtly adapted and responded to this new system in light of the BBC's new structures. Programmes for less academic pupils, most likely those attending secondary modern schools, aired on the Home Service, whilst more advanced programming was offered for older, grammar school pupils on the Third Programme.

Rhoda Power had always considered her 'oral vision' theory and illustrated talk technique most applicable to non-academic pupils. As Britain moved into a televisual age, this pedagogical thinking was preserved. The BBC did not make educational films between the wars; before 1939 educational films in Britain had developed unevenly, via partnerships between private companies and ancillary educational organisations. The state did not become fully involved in the production of History teaching films until the Second World War. ${ }^{74}$ As early as 1943 Rhoda Power had warned that the BBC should be working urgently on a policy and material for television, which would undoubtedly be the new mass educational medium. ${ }^{75}$ She worked as an advisor on educational films for the Ministry of Education during the war, feeding her pedagogical ideas into suggestions for content. ${ }^{76}$ For example, she commented on an early cut of one film as follows: "I think that many children, especially those in the "B" string, look rather than listen, and are more likely to remember words spoken by some person in the picture. ${ }^{77}$ 
The BBC did not run its first pilot television broadcasts for schools until 1952, and the service did not become mainstream until the 1960 s. $^{78}$

Nick Whines, who joined the BBC as a radio producer in the Schools Broadcasting Department in September 1972, described how Rhoda Power's radio scripts were still being used as late as 1970. He was hired to take the broadcasts in a new direction. As the British secondary school system was once again reorganised, this time into larger, non-selective comprehensive schools, the BBC developed links with teacher-training colleges in order to keep abreast of developing pedagogy. ${ }^{79}$ Television lessons were considered to be particularly suited to the mixed-ability classes typical of the large new comprehensives. $^{80}$

\section{Conclusion}

The BBC's educational project between the 1920s and the 1950s was technologically innovative but pedagogically conservative. In its attempts to create educational material that was widely accessible to a full range of listeners and to promote democratic citizenship, History broadcasting for schools on the BBC simultaneously reinforced the social stratification of knowledge in Britain. This was a distinctively mid-century discourse, carried from the interwar expansion of education and democratic enfranchisement, across the Second World War, and into the deferential but affluent years of the 1950s. Women were able to produce and disseminate popular knowledge in this space, as long as their expertise remained tied to pedagogy and education. Whilst her sister Eileen Power did not broadcast any full series after 1936 following a disagreement with Mary Somerville about the politicization of World History broadcasting, Rhoda Power's more moderate stance aligned with the BBC's gendered expectations about the limits of female expertise. ${ }^{81}$

\section{BIBLIOGRAPHY}

\section{Archival sources}

BBC Written Archives Centre, Caversham.

Girton College Archive, University of Cambridge, Eileen Power papers and Rhoda Power papers. Institute of Education Archives and Special Collections, University College London, History in Education Project Archive.

London Metropolitan Archives, Clerkenwell, London. 


\section{Published primary sources}

BBC, New Ventures in Broadcasting: A Study in Adult Education (London, BBC, 1928).

BBC, Radio Times.

BBC, The BBC Handbook 1940 (London, BBC, 1940).

BBC, The BBC Yearbook 1930 (London, BBC, 1930).

BBC, The BBC Yearbook 1931 (London, BBC, 1931).

$\mathrm{BBC}$, The Listener.

Carnegie Trust, Educational broadcasting: report of a special investigation in the county of Kent during the year 1927 (Dunfermline, Carnegie Trust, 1928).

Elliott, B. J., 'BBC History Talks for schools: the early years', Teaching History 4 (1976), pp. 350-8.

Elliott, B. J., 'Genesis of the History Teaching Film', Teaching History 19 (1977), pp. 3-6.

Fawdry, Kenneth, Everything but Alf Garnett: A personal view of BBC School Broadcasting (London, BBC, 1974).

Hankin, G. T., 'The Poison of History', History 23 (1938), pp. 139-40.

Palmer, Richard, School broadcasting in Britain (London, BBC, 1947).

Portway Dobson, Dina, 'Wireless lessons in History', History 15 (1930), pp. 34-8.

Power, Rhoda and Eileen Boys and Girls of History (Cambridge, Cambridge University Press, 1926).

Power, Rhoda, Great People of the Past (Cambridge: Cambridge University Press, 1932).

Power, Rhoda, How it Happened (Cambridge: Cambridge University Press, 1930).

Power, Rhoda, Under Cossack \& Bolshevik (London, Methuen, 1919).

Power, Rhoda, We too were there (London: George Allen \& Unwin, 1956).

Power, Rhoda, We were there (London: George Allen \& Unwin, 1955).

Somerville, Mary, 'Miss Rhoda Power: Influence on School Broadcasting', The Times, 13 March 1957, p. 13.

\section{Secondary sources}

Berg, Maxine, A woman in history: Eileen Power, 1889-1940 (Cambridge, Cambridge University Press, 1996).

Briggs, Asa, The History of Broadcasting in the United Kingdom. Volume II: The Golden Age of Wireless (Oxford, Oxford University Press, 1995).

Briggs, Asa, The History of Broadcasting in the United Kingdom. Volume III: The War of Words (Oxford, Oxford University Press, 1995).

Colpus, Eve, 'Women, Service and Self-actualization in Inter-War Britain', Past \& Present 238 (2018), pp. 197-232.

Cox, Gordon, 'School music broadcasts and the BBC 1924-47', History of Education 25 (2006), pp. 363-71. 
Crook, David, 'School Broadcasting in the United Kingdom: An Exploratory History', Journal of Educational Administration and History 39 (2007), pp. 217-26.

Freeman, Mark, "An advanced type of democracy'? Governance and politics in adult education c. 1918-1930', History of Education 42 (2013), pp. 45-69.

Hajkowski, Thomas, The BBC and national identity in Britain, 1922-53 (Manchester, Manchester University Press, 2010).

Hendy, David, 'Painting with Sound: The Kaleidoscopic World of Lance Sieveking, a British Radio Modernist', Twentieth Century British History 24 (2013), pp. 169-200.

Hendy, David, 'The Great War and British Broadcasting: The Emotional Life in the Creation of the Early BBC', new formations 82 (2014), pp. 82-99.

Howsam, Leslie, Past into print: the publishing of history in Britain 1850-1950 (London, British Library, 2009).

Keating, Jenny, Sheldon, Nicola, and Cannadine, David, The right kind of history: teaching the past in twentieth-century England (Basingstoke; New York, Palgrave Macmillan, 2011).

LeMahieu, Daniel L. 'Entrepreneur of Collectivism: Reith of the BBC', in Susan Pedersen and Peter Mandler (eds.), After the Victorians: Private Conscience and Public Duty, 1880-1950, (London, Routledge, 1994), pp. 188-206.

McCarthy, Helen, Women of the World: The Rise of the Female Diplomat (London, Bloomsbury, 2015).

McKibbin, Ross, Classes and cultures: England 1918-1951 (Oxford, Oxford University Press, 1998).

Melman, Billie, 'Under the Western Historian's Eyes: Eileen Power and the Early Feminist Encounter with Colonialism', History Workshop Journal 42 (1996), pp. 147-68.

Murphy, Kate, Behind the Wireless: A History of Early Women at the BBC (London, Palgrave Macmillan, 2016).

Nicholas, Sian, 'The People's Radio? The BBC and its audience 1939-45', in Nick Hayes and Jeff Hill (eds.) Millions Like Us? British Culture in the Second World War (Liverpool, Liverpool University Press, 1999), pp. 62-92.

Nott, James, Music for the people: popular music in Britain between the wars (Oxford, Oxford University Press, 2002).

Paterson, Lindsay, 'The significance of the Education (Scotland) Act, 1918', Scottish Affairs 27 (2018), pp. 401-24.

Robinson, Wendy, 'Historiographical Reflections on the 1902 Education Act', Oxford Review of Education 28 (2002), pp. 159-72.

Scannell, Paddy and Cardiff, David, A social history of British broadcasting. Vol 1, 1922-1939: Serving the nation (Oxford, Basil Blackwell, 1991).

Tebbutt, Melanie, 'Listening to Youth? BBC Youth Broadcasts during the 1930s and the Second World War', History Workshop Journal 84 (2017), pp. 214-33.

Turnball, Annemarie, 'Learning Her Womanly Work: the Elementary School Curriculum, 1870-1914', in Felicity Hunt (ed.), Lessons for Life: the Schooling of Girls and Women 1850-1950 (Oxford, Basil Blackwell, 1987), pp. 83-100.

Yusaf, Shundana, Broadcasting Buildings: Architecture on the Wireless, 1927-1945 (Cambridge, Mass, MIT Press, 2014). 


\section{NOTES}

1. Naomi Mitchison, 'Teaching the Teachers', The Listener, 10 October 1934, p. 615.

2. Daniel L. LeMahieu, 'Entrepreneur of Collectivism: Reith of the $B B C$ ', in Susan Pedersen and Peter Mandler (eds.), After the Victorians: Private Conscience and Public Duty, 1880-1950, (London, Routledge, 1994), pp. 188-206; James Nott, Music for the people: popular music in Britain between the wars (Oxford, Oxford University Press, 2002); Shundana Yusaf, Broadcasting Buildings: Architecture on the Wireless, 1927-1945 (Cambridge, Mass, MIT Press, 2014).

3. David Hendy, 'The Great War and British Broadcasting: The Emotional Life in the Creation of the Early BBC', new formations 82 (2014), pp. 82-99.

4. See for example, David Crook, 'School Broadcasting in the United Kingdom: An Exploratory History', Journal of Educational Administration and History 39 (2007), pp. 217-26; Gordon Cox, 'School music broadcasts and the BBC 1924-47', History of Education 25 (2006), pp. 363-71.

5. For example, neither of the following key studies of BBC broadcasting include broadcasts for schools: Paddy Scannell and David Cardiff, A social history of British broadcasting. Vol 1, 1922-1939: Serving the nation (Oxford, Basil Blackwell, 1991); Thomas Hajkowski, The BBC and national identity in Britain, 1922-53 (Manchester, Manchester University Press, 2010).

6. Asa Briggs, The History of Broadcasting in the United Kingdom. Volume II: The Golden Age of Wireless (Oxford, Oxford University Press, 1995), p. 173.

7. BBC, New Ventures in Broadcasting: A Study in Adult Education (London, BBC, 1928).

8. Mark Freeman, "An advanced type of democracy'? Governance and politics in adult education c.1918-1930', History of Education 42 (2013), pp. 45-69, at p. 46.

9. Briggs, The Golden Age, pp. 201-2.

10. BBC, New Ventures, p. 28. pp. 23-25.

11. Cf. 'Active and Passive Culture', The Listener, 7 June 1933, p. 892.

12. Briggs, The Golden Age, pp. 116-7; Kate Murphy, Behind the Wireless: A History of Early Women at the BBC (London, Palgrave Macmillan, 2016), pp. 168-75.

13. Annemarie Turnball, 'Learning Her Womanly Work: the Elementary School Curriculum, 1870-1914', in Felicity Hunt (ed.), Lessons for Life: the Schooling of Girls and Women 1850-1950 (Oxford, Basil Blackwell, 1987), pp. 83-100; Wendy Robinson, 'Historiographical Reflections on the 1902 Education Act', Oxford Review of Education 28 (2002), pp. 159-72.

14. Lindsay Paterson, 'The significance of the Education (Scotland) Act, 1918', Scottish Affairs 27 (2018), pp. 401-24.

15. Ross McKibbin, Classes and cultures: England 1918-1951 (Oxford, Oxford University Press, 1998), pp. 206-71.

16. 'BBC Memorandum: School Broadcasting', June 1932: BBC Written Archives Centre, Caversham (hereafter BBC WAC), S68/9; B. J. Elliott, 'BBC History Talks for schools: the early years', Teaching History 4 (1976), pp. 350-8, at p. 351, p. 357.

17. J. C. Stobart to G. Gater, 13 June 1924: London Metropolitan Archives, Clerkenwell, London (hereafter LMA), LCC/EO/GEN/01/083.

18. 'Meeting of the Education Advisory Committee', 30 June 1926: LMA, LCC/EO/GEN/01/083.

19. Educational broadcasting: report of a special investigation in the county of Kent during the year 1927 (Dunfermline, Carnegie Trust, 1928). Cf. Kenneth Fawdry, Everything but Alf Garnett: A personal view of BBC School Broadcasting (London, BBC, 1974), pp. 43-5.

20. Briggs, The Golden Age, pp. 176-7.

21. Murphy, Behind the Wireless, pp. 159-67.

22. BBC, The BBC Yearbook 1930 (London, BBC, 1930), pp. 227-8.

23. 'BBC Memorandum: School Broadcasting'.

24. Hajkowski, The BBC and national identity, p. 168.

25. Briggs, The Golden Age, p. 176. 
26. 'Experts in Council', The Listener, 4 June 1930, p. 976.

27. 'A Still Higher Standard', The Listener, 18 September 1929, p. 372.

28. 'LR/164 - Adolescent Listening and School Broadcast', 6 September 1940: BBC WAC, R9/9/4.

29. Dina Portway Dobson, 'Wireless lessons in History', History 15 (1930), pp. 34-8.

30. Leslie Howsam, Past into print: the publishing of history in Britain 1850-1950 (London, British Library, 2009), pp. 95-6. Her publications included (with Eileen) Boys and Girls of History (Cambridge, Cambridge University Press, 1926); How it Happened (Cambridge: Cambridge University Press, 1930); Great People of the Past (Cambridge: Cambridge University Press, 1932); We were there (London: George Allen \& Unwin, 1955); We too were there (London: George Allen \& Unwin, 1956).

31. Mary Somerville, 'Miss Rhoda Power: Influence on School Broadcasting', The Times, 13 March 1957, p. 13.

32. Maxine Berg, A woman in history: Eileen Power, 1889-1940 (Cambridge, Cambridge University Press, 1996), pp. 230-1.

33. Helen McCarthy, Women of the World: The Rise of the Female Diplomat (London, Bloomsbury, 2015), pp. 124-8.

34. Berg, A woman in history, pp. 14-27; 'Special Collections: Rhoda Power, Certificates and Photograph', 1912-8: BBC WAC, S68/2.

35. Rhoda Power, Under Cossack \& Bolshevik (London, Methuen, 1919); 'People You Hear...Described by Guy Fletcher 'World History", Radio Times, 21 June n.d.: Girton College Archive, University of Cambridge (hereafter GCA), GCPP Power, E $1 / 1$.

36. Rhoda Power, 'Russia diaries, volume 1', 21 January 1917-21 August 1917: GCA, GCPP Power, R 1/1; 'Russia diaries, volume 2', 22 August 1917-8 April 1918: GCA, GCPP Power, R 1/2.

37. 'BBC Memorandum: Miss Rhoda Power', 23 June 1936; 'BBC Memorandum: Miss Rhoda Power', 16 January 1939; 'BBC Memorandum: Miss Rhoda Power', July 1943: BBC WAC, R94/2 962 2.

38. 'Programme Contract Staff Annual Report: Power, Rhoda', 1 May 1945: BBC WAC, R94/2 962 2; 'Rhoda Power contract log', 22 July 1937-25 April 1948; 'Rhoda Power contract log', 22 July 1937-9 March 1957; 'Note on School Broadcasts scriptwriters on Programme Contract', 5 November 1945: BBC WAC, R94/2 962 2. For context see Murphy, Behind the Wireless, appendix 3 and p. 116.

39. 'Rhoda Power contract log', 22 July 1937-9 March 1957.

40. Rhoda Power to Hamilton Marr, 30 August 1936: BBC WAC, RCONT1 Power, Rhoda - Copyright File 1.

41. 'Rhoda Power: Letters from America: Letter 6', 25 August 1946: GCA, GCPP Power, R 2/1.

42. 'Rhoda Power: Letters from America: Letter 3', 10 April 1947: GCA, GCPP Power, R 2/3.

43. Eileen Power to George Coulton, 20 March 1921: GCA, GCPP Power, E 2/2.

44. Billie Melman, 'Under the Western Historian's Eyes: Eileen Power and the Early Feminist Encounter with Colonialism', History Workshop Journal 42 (1996), pp. 147-68.

45. Berg, A woman in history, pp. 162-3.

46. Rhoda Power, 'Dramatization in the Teaching of History', 30 April 1932: BBC WAC, S68/9.

47. Rhoda Power, 'Broadcasting History Lessons', 25 February 1933: BBC WAC, S68/9.

48. Elliott, 'BBC History Talks for schools', p. 353. Emphasis true to source.

49. Murphy, Behind the Wireless.

50. 'Foreword by Mary Agnes Hamilton', Radio Times, 16 November 1934, p. 533.

51. Cf. Eve Colpus, 'Women, Service and Self-actualization in Inter-War Britain', Past \& Present 238 (2018), pp. 197-232.

52. BBC, The BBC Yearbook 1931 (London, BBC, 1931), p. 235.

53. Somerville, 'Miss Rhoda Power'.

54. Power, 'Broadcasting History Lessons'. 
55. Rhoda Power to Jacquetta Hawkes, 2 February 1948; Dorothy Hartley to Rhoda Power, 17 May 1938: BBC WAC, S68/6/1. Cf. David Hendy, 'Painting with Sound: The Kaleidoscopic World of Lance Sieveking, a British Radio Modernist', Twentieth Century British History 24 (2013), pp. 169-200, at p. 196.

56. Rhoda Power to Edith, 15 April 1935: BBC WAC, Rhoda Power talks file I.

57. Elliott, 'BBC History Talks for schools', p. 354.

58. 'Caxton's Printing Press', 19 June 1933: BBC WAC, RCONT1 Power, Rhoda - Copyright File 1.

59. Cf. Melanie Tebbutt, 'Listening to Youth? BBC Youth Broadcasts during the 1930s and the Second World War', History Workshop Journal 84 (2017), pp. 214-33, at p. 226.

60. 'New Schools Set Up', 25 March 1937, 14:00; 'Diet', 17 June 1937, 14:30, National Service.

61. 'Interlude: Round the Clock in a Thirteenth Century Burgh', 13 February 1935, 14:10, Scottish Regional Programme.

62. Fawdry, Everything but Alf Garnett, p. 45.

63. Lucinda Lord to BBC, 29 December 1934: BBC WAC, S68/1.

64. G. T. Hankin, 'The Poison of History', History 23 (1938), pp. 139-40, at p. 139.

65. 'Broadcasts to Schools September 1936 to June 1937', 1936, p. 22, p. 42, p. 45; 'Broadcasts to Schools September 1937 to June 1938', 1937, p. 28, p. 46, p. 52, p. 57; 'Broadcasts to Schools September 1938 to June 1939', 1938, pp. 28-32; 'Broadcasts to Schools September 1939 to June 1940', 1939, pp. 26-30. All BBC WAC, Box S322/235 - Adams, Mary (Talks, Radio) - BBC Publications: Broadcasts to Schools.

66. 'BBC Memorandum: Fortnightly Courses in History', 25 October 1938: BBC WAC, R16/421/1.

67. BBC, The BBC Handbook 1940 (London, BBC, 1940), pp. 68-72.

68. Crook, 'School Broadcasting'; Asa Briggs, The History of Broadcasting in the United Kingdom. Volume III: The War of Words (Oxford, Oxford University Press, 1995), pp. 538-9, p. 636; Richard Palmer, School broadcasting in Britain (London, BBC, 1947), p. 83.

69. Sian Nicholas, 'The People's Radio? The BBC and its audience 1939-45', in Nick Hayes and Jeff Hill (eds.) Millions Like Us? British Culture in the Second World War (Liverpool, Liverpool University Press, 1999), pp. 62-92.

70. Hajkowski, The BBC and national identity, p. 161, p. 192.

71. BBC, BBC Handbook 1940, p. 72.

72. 'Memorandum from Miss Helen Duncan to DSB, "World History"', 16 January 1943: BBC WAC, $\mathrm{R} 16 / 421 / 2$.

73. Fawdry, Everything but Alf Garnett, p. 50.

74. B. J. Elliott, 'Genesis of the History Teaching Film', Teaching History 19 (1977), pp. 3-6.

75. Rhoda Power, 'BBC Memorandum: My work 1943-44', 5 March 1943: BBC WAC, R94/2 9622.

76. Somerville, 'Miss Rhoda Power'.

77. Rhoda Power to Jacquetta Hawkes, 15 December 1947: BBC WAC, S68/6/1.

78. Jenny Keating, Nicola Sheldon, and David Cannadine, The right kind of history: teaching the past in twentieth-century England (Basingstoke; New York, Palgrave Macmillan, 2011), p. 163.

79. 'Transcript of an interview with Nick Whines', 19 January 2010: History in Education Project Archive, Institute of Education Archives and Special Collections, University College London, HEP/ $4 / 45$.

80. Fawdry, Everything but Alf Garnett, pp. 9-12.

81. On Eileen at the BBC see Berg, A woman in history, pp. 232-4. 


\section{ABSTRACTS}

This article considers the relationship between $\mathrm{BBC}$ radio and mass secondary education in Britain through the life of innovative schools History broadcaster Rhoda Dolores Le Poer Power (1890-1957). It argues that during the mid-twentieth century the BBC was closely aligned with mainstream educational thinking, and that its broadcasting structures and practices largely reproduced the stratification of social knowledge seen in Britain's evolving secondary school system between the 1920s and the 1950s. Through the work of Rhoda Power, the article also shows how the $\mathrm{BBC}$ created unique spaces for women to participate in and lead educational thinking, at a time when their influence within elite education in universities was diminishing.

Cet article analyse le lien entre la radio $\mathrm{BBC}$ et la généralisation de l'enseignement secondaire au Royaume-Uni à travers la vie de Rhoda Dolores Le Poer Power (1890-1957), animatrice et historienne au rôle novateur. Cet article démontre que, au milieu du vingtième siècle, les positionnements éducatifs de la $B B C$ se fondaient sur une approche très traditionnelle de l'éducation. La structure même de cette institution de radiodiffusion se faisait ainsi le reflet de la stratification de la connaissance qui sous-tendait alors la société britannique entre les années 1920 et les années 1950. A travers l'étude du travail de Rhoda Power, cet article explore la manière dont la $\mathrm{BBC}$ a toutefois permis d'ouvrir des espaces de participation relativement uniques pour les femmes qui leurs permirent de contribuer aux débats sur l'éducation, alors même que leur influence au sein des universités était en déclin.

\section{INDEX}

Mots-clés: BBC, enseignement, Rhoda Power, école, pédagogie, technologie, femmes

Keywords: BBC, education, schooling, Rhoda Power, pedagogy, women, technology

\section{AUTHOR}

\section{LAURA CARTER}

Université de Paris, LARCA, CNRS, F-75013 Paris, France

Dr Laura Carter is a Lecturer in British History (maître de conférences en histoire britannique) at the Université de Paris, LARCA, CNRS (UMR 8225). Her research focuses on education, popular culture, and social change in twentieth-century Britain. Her first book, Histories of Everyday Life: The Making of Popular Social History in Britain, 1918-1979, will be published by Oxford University Press in 2021. 